\title{
Charms and Incantational Magic of the Northern Russians (In Records of the Early Twenty-first Century)
}

\author{
Iulia Krasheninnikova \\ Institution of Language, Literature and \\ History of the Komi Scientific Center \\ Ural Division of the Russian Academy of Science (RAS) \\ Syktyvkar, Russia
}

\begin{abstract}
\end{abstract}
The folklore tradition found in the village of Loima and other settlements belonging to the Loima rural administration of the Priluzskii region of the Komi Republic took shape in an environment that was in close contact with the Komi population. This factor promoted the maintenance of traditional Russian forms of folk culture. Researchers have observed that the inherited folklore of such traditions as Loima's preserve genres and elements of folk belief from their historical motherland. These elements are manifest in ritual folklore, in tales, and in mythological personages, among other folklore forms. The object of the present study is incantation-conjuration texts as they were recorded in the early twenty-first century $(2004,2006)$. These texts include charms (zagovory $i$ prigovory), incantations (zaklinaniia), well-wishing (blagopozhelaniia), and ritual dialogues that accompany healing, lifecycle, calendrical, animal-husbandry, and other rituals.

On the "folklore map" of the Komi Republic, we can identify several compact, localized Russian traditions that were formed in an alien ethnic environment. One of these is the folklore tradition found in the village of Loima and other settlements belonging to the Loima rural administration of the Priluzskii region [raion] - a region which is predominantly Komi. The village of Loima, first mentioned in 1620 in the patrol book of the Sol'vychegodsk district [uezd], belonged variously to Sol'vychegodsk, Lal'sk and Ust'-Sysol'sk districts of Vologda province [guberniia] [Zherebtsov 1994: 139]; it was annexed by the Komi Republic in 1921. The Loima tradition emerged in the eighteenth and nineteenth centuries, when Russian migrants moving from northern and north-eastern Russian provinces along the merchant passage to Viatka and Siberia settled in the Loima area [Vlasov and Kaneva 2006: 25]. 
Loima's folk culture thus took shape in an environment that was in close contact with the Komi population. This factor promoted the maintenance of "traditional forms of folk culture as a means of reinforcing 'otherness' amidst the indigenous [Komi] population" [Vlasov and Kaneva 2006: 24-25] and this phenomenon occurred within the historical memory of the Loima Russians. Researchers have observed that the inherited folklore of such traditions as Loima's preserve genres and elements of folk belief from their historical motherland. These elements are manifest in ritual folklore, in tales, and in mythological personages, among other folklore forms [Vlasov and Kaneva 2006: 25].(1)

The object of the present study is incantation-conjuration texts as they were recorded in the early twenty-first century $(2004,2006)$.(2) These texts include charms (zagovory $i$ prigovory), incantations (zaklinaniia), well-wishing (blagopozhelaniia), and ritual dialogues that accompany healing, life-cycle, calendrical, animal-husbandry, and other rituals. The Loima tradition is characterized by a considerable body of thematically varied incantation-conjuration texts. The most representative texts are associated with the treatment of physical and mental diseases and animal husbandry rituals. Texts dealing with love, social life (promoting family welfare, preventing fire, traveling, business and trading, separation of spouses, etc.), and texts associated with specific agricultural tasks and calendrical dates are less frequently encountered. The content of this article is dictated by available texts.

Today Loima villagers do not actively use incantation-conjuration texts in animal husbandry.(3) Still, analysis of material devoted to the theme of magical interdictions and prescriptions reveals that a complete system of safeguards, interdictions, and prescriptions associated with the buying and selling of animals and with leading the newly-acquired animal into the cow-barn, or cattle-shed existed among Northern Russian rural populations until very recently. This system was intended to preserve the animal's health, fertility, and the quality and quantity of food stuffs and wool/hide produced by the animal. Recorded evidence applies mainly to large, horned livestock. Data on other domestic animals are scanty and sporadic. Similar incantations are still used, notably in some districts of the Russian North and in parts of Ukraine [Adon'eva and Ovchinnikova 1993: 32-42; Kukharenko 2007: 53-76].

Among the poetic texts proper, the incantations most widely disseminated were those for the first pasture, for the first entry of animals into the cattle-shed, for unlocking milk, for calving, and for preventing 
the loss of a cow. The characteristic features of the majority of the texts are their "simplicity of content and brevity of narration" [Eleonskaia 1917: 7]. Thus, when leading a new animal into the cattle-shed, the villagers uttered charms composed of several structural elements. The opening (zachin) contains an address to the house spirit (domovoi) as "grandpa-neighbor" (dedushko-sosedushko) or "neighbor-bear" (sosedushka-medvedushka). The body is laconic and consists of an imperative expressing the wish that the animal be well-cared for:

Дедушко-суседушко, пусти коровушку на подворье, пой, корми и гладь! [ИЯЛИ: ВФ 1513-27];

[Grandpa-neighbor, let the little cow into the yard, water, feed, and stroke her!]

Дедушко-суседушко, люби мою коровушку. Пой да корми, по шерстке гладь! [ИЯЛИ: ВФ 1515-20];

[Grandpa-neighbor, love my little cow. Water and feed her, and stroke her hide!]

Дедушко-суседушко, храни моего скота, пой да корми, да люби! [ИЯЛИ: ВФ 1515-38];

[Grandpa-neighbor, keep my cattle safe, water and feed them, and love them!]

Дедушко-суседушко, пусти на подворье, пой, корми, и рости [ИЯЛИ: ВФ 1518-33];

[Grandpa-neighbor, let [my animal] into the yard, water, feed and help it grow]

Дедушко-суседушко, пусти нашу коровушку, пой, корми, ухаживай, по глотке поглаживай [ИЯЛИ: ВФ 1526-11].

[Grandpa-neighbor, let our little cow in, water, feed, take care of her, stroke her on the throat]

The invariable element in the conjuration wish is the three-part formula: "let in, water, feed"; this formula may be amplified by additional, optional components (love, stroke, grow, keep, take care, and others).(4)

The ritual of the first pasture was accompanied mostly by incantations using comparative formulas. For example, a belt was removed from the body and placed on the threshold. After the cow had passed over the threshold, the belt was replaced with following words:

Как пояс меня держится, так и коровушка держись дому [ИЯЛИ: ВФ 1513-28]; 
[As the belt holds to me, so, little cow, hold to the home]

also:

как вербочка дома держится, так и . . .

как камень лежит, не шелохнется, так и . . .

[As a pussy-willow holds to the house, so ...

As a stone lies, without stirring, so ...]

etc.

At the first pasture the villagers uttered brief, protective texts with incantational elements:

спаси и сохрани мою коровушку ...

солнышко на закат и коровушка домой быстрехонько бежи! . . .

[save and keep my little cow ...

the sun is setting, and little cow, run home fast as fast can be! ...]

At calving time, laconic incantations expressed the wish that "a new soul be allowed to enter this world":

Распускай мою Коровушку! Душу спасай, другую выпускай на белый свет!

Господь Боже! Чернушеньку мою спасай, а теленочка на свет выпускай!) [ИЯЛИ: ВФ 1515-22, 23].

[Loosen my Little Cow! [referring here to dilation] Save her soul, let the other [soul] enter the wide world!

Lord God! Save my Chernushen'ka, and let the calf come into the world!]

The notion that a cow's lack of milk is caused by the evil eye is persistent, which explains the dissemination of rituals and incantations intended for the "unlocking" (otpiranie) of milk.(5) Uttering the incantation, the villager would stroke the cow from head to udder and say:

Из жилочки в вымечко, из вымечка в титечки, из титечек в подоенку, стой да бухай, дой да слухай, как я тебя люблю, так и ты меня люби, сейчас же молоко отпускай быстрехонько. Будьте мои слова крепки, лепки навеки. Аминь [АА 2006].

[From vein to udder, from udder to teats, from teats to milk pail, stand and pour, give milk and hear how much I love you, and so must you love me; now let the milk pour fast as fast can be. Let my words be strong and sticky forever. Amen] 
Then they began the milking. The informant indicates that the stroking must start from the head (the action represents a distinctive form of massage), because "there is a connecting vein the size of a fist" in the animal's throat. Perhaps the incantation to the house spirit:

Дедушко-суседушко, пусти нашу коровушку, пой, корми, ухаживай, по глотке поглаживай [ИЯЛИ: ВФ 1526-11],

[Grandpa-neighbor, let our little cow in, water, feed, take care of her, stroke her on the throat]

reflects this idea that a vein in the throat of the cow affects the quantity and quality of milk.

Another incantation for "unlocking milk" is characterized by the presence of traditional structural elements and the classic poetics of the incantation (an opening passage, a description of the chief personage's initial movement toward the important sacral object, a catalog of magic helpers and a description of their actions, and the use of traditional epithets):

Я, раба Божья Александра, пойду, перекрестясь, пойду, благословясь, из избы в двери, из дверей на улицу, с улицы в чистое поле. В чистом поле на высоком холме стоит храм. В храме стоит престол, на престоле стоит белое блюдо, в белом блюде лежат ключи. Я, раба Божья Александра, брошу ключи в океан-море. Сходят за этими ключами в океан-море рабы Божьи Мария, Параскева и Клавдия. Принесут золотые ключи. Я этими ключами открою все молочные колодчики, все молочные жилочки. Потечет молочко по молочным колодчикам, потечет молочко по молочным жилочкам в вымечко, из вымечка в титечки, из титечек в ведерышко для рабы Божьей Александры. Будьте слова крепки, лепки, тверды и правильны к вымени моей коровушки [ИЯЛИ: АФ 1536-36].

[I, the handmaiden of God, Aleksandra, will go crossing myself, will go blessing myself, from the house to the door, from the door to the road, from the road to the open field. In the open field is a temple on a high hill. In the temple is an altar, on the altar is a white plate, on the white plate are keys. I, the handmaiden of God, Aleksandra, will throw the keys into the ocean-sea. The handmaidens of God Mariia, Paraskeva, and Klavdiia will go to the ocean-sea for these keys. They will bring back golden keys. With these keys I will open all the milk wells, all the milk veins. The milk will run into milk wells, the milk will run through milk veins to the udder, from the udder to the teats, from the teats to the milk pail for the handmaiden of God, Aleksandra. Be my words strong, sticky, firm and right for my cow's udder.]

The image of an all-devouring pike (shchuka-kalyga) with iron teeth and tin eyes appears in an incantation to promote good appetite in animals: 
Как щука-калыга, железные зубы, оловянные глаза, ест-поедает, так же чтоб мои поросятки, телятки ели-пили, сопели, в посудинке ничего не оставляли. Горькое, кислое, соленое пусть им кажется медом, сладкой патокой. Ешьте, сопите, жрите, в посудинке ничего не оставляйте. Как сиги, караси в синем море гладки, чисты, здоровы, также чтоб мои поросятки были чисты, гладки, здоровы. Во имя отца и сына, и святого духа. Аминь [ИЯЛИ: ВФ 1531-33].

[As the iron-toothed, tin-eyed pike gobbles up everything, so let my piglets and calves gobble up everything, grunting, leaving not a drop in the food trough. Let the bitter, the sour, and the salty seem as honey, as sweet syrup, to them. Eat, grunt, gorge, and leave nothing in the food trough. As whitefish and carp in the blue sea are smooth, clean, healthy, so let my piglets be clean, smooth, healthy. In the name of the Father and the Son and the Holy Spirit. Amen.]

The incongruous use of the "pike" image here may be explained by the content of another incantation from this informant's repertoire, specifically in an incantation to ward off diseases, where the "pike" eats up "unfortunate accidents, evil eyes" (see below).

Materials about animal husbandry rituals are numerous. The first pasturing of cattle fell on St. George's Day.(6) If the weather was cold and grass was sparse, the ritual of first pasture was performed symbolically, and the animal was led out of the cattle-shed for only a short period of time. Pussy-willow, salt, bread, and an icon were used in the ritual. Branches of pussy-willow (in local terminology, mas ' $k i$ ) were kept on the icon shelf (bozhnitsa) from Palm Sunday (Verbnoe voskresen'e).(7) The willow branches were used to stroke and lightly strike the animal from head to tail. After the animal returned from pasture, the mistress would affix the pussy-willow branch above the door of the cattle-shed or in the house under the tie beam and utter incantations in which she mentioned the items used in the ritual:

Как вот эта вербочка домой пришла и дома будёт спать, так же мой скотичек ходил домой.

Как эта иконка дому держалася, вербочки дому держалися, дак так чтобы у нас коровушка дому держалася. Солнышко на закат, и коровушка бежи быстрехонько домой. [AА, 2006].

[Just as this pussy-willow came home and will sleep at home, so let my cattle come home.

Just as this icon has held to home, and the pussy-willows have held to home, so let our little cow hold to home. The sun is setting, so run home, little cow, fast as fast can be.]

At first pasture, a piece of salted bread and some salt were given to each animal on the farm. The bread and salt used for this ritual was 
placed before the icons on Holy Thursday (8). The villagers considered that, once they performed this action, their animals would not walk past their home and would be guarded from the evil eye or spoiling. Faith in the active power of salt that had been placed near icons on Holy Thursday (also "velikodennaia," "chetvergovaia" salt) must be emphasized. Salt which "overnighted" near the icons and which was kept for the entire year, until the following Holy Thursday, was given to ailing cattle and used at calving. To keep the animals safe from the evil eye, the salt was sprinkled around the cattle-shed. Salt that had been kept for three years was thrown into the footsteps of any person thought capable of causing spoiling. Villagers also washed dishes that had been tainted [by mice, cockroaches - ИЯЛИ: ВФ 1544-28] with this salt.

На Великий Четверг соль под божницу поставишь, тут она заночует, под иконой. «Как соль не портится, так чтоб скот не портился» - это вот скажешь. Солью-то посыплешь потом на их. Я тебе скажу: корова отелится, берешь соли вот так немного, горсть, посыплешь на корову, посыплешь на теленочка. Она лижет, чтобы не портился. Бывает, людито всякие глаза-то. Четверговая соль, она весь год должная быть. Ее приберешь. Потом мало ли че со скотиной, вот так на кусочек возьмешь этой соли и дашь [ИЯЛИ: АФ 1544-12].

[On Great Thursday, they place the salt under the icon shelf, here it will spend the night, beneath the icon. "As salt does not spoil, so should the cattle not spoil" - this you will say. Then you will sprinkle them [the animals Iu.K.] with this salt. I'm telling you: when a cow calves, you will take a little salt, just a small handful, sprinkle it on the cow, sprinkle it on the calf. She will lick the calf and so it will not be spoiled. It happens that people have different kinds of eyes. (9) Thursday salt should be available all year. Keep it safe. Who knows what might happen to the cattle, and then you can take some of this salt and give it to them.]

If new animals did not become readily accustomed to the cattleshed, they were led out of the shed on Holy Thursday with an incantation, for example:

Великий Четверг, соверши силу великую над коровушками, чтоб не гибли, не падали, чтоб жили, были здоровыми

На Великий Четверг отвожу все неприятности, все невзгоды, чтоб коровушки не гибли, не дохли, не сохли, чтоб были здоровы и плодливы [ИЯЛИ: АФ 1538-10, 11].

[Holy Thursday, exercise your great power over the little cows, so that they do not perish, do not fall, so that they live and be healthy.

On Holy Thursday I ward off all troubles, all misfortunes, so that the little cows do not perish, do not die, do not dry up, so that they become healthy and fertile] 
Rituals that accompany the relocation of a newly-purchased animal into its new cattle-shed are also widely disseminated. The purpose of these rituals is to ensure the animal's successful "transfer" to its new home ("so that it would not pine for its old home") and the preservation of its productivity. One of our informants described such a rite, which consists of several interconnected mini-rites, each of which could be performed independently. A small stone, some hay, or moss taken from the seller's yard was placed under the crib or manger, accompanied by the following words:

гостья, тут погостили, теперь пойдем к нам погостить

[Guest, you visited here (meaning the cow's previous home), now let's go visit our place]

In the milking shed, the new owners placed a large pail full of water (the informant mentions a 15-liter pail). Leading the animal into the shed, they first addressed the house-spirit:

Суседушко-медведушко, пусти мою коровушку на подворьицё, гладь да добрей, гладь да добрей. И привела, и принесла с собой молочко густое, сметану густую, желтоё маслицё.

[Neighbor-bear, let my cow into the yard, stroke her and stroke most kindly, stroke her and stroke most kindly. That, as she is led in, she may bring with her rich milk, thick cream, yellow butter]

Then the cow was sprinkled with salt from head to tail while these words accompanied the action:

Как эта соль дому держалася, не портилася, так чтобы у меня скотинушка не портилась, держалась бы дому. Будьте мои слова крепки, лепки навеки. Аминь.

[As this salt held to the home and did not spoil, so may my cow not be spoiled and hold to home. Let my words be strong and sticky forever. Amen]

After that, the large pail was placed next to the cow with the words,

Как та коровушка доила, так щтёбы моя коровушка доила больше - по пятнадцатилитровому ведру, и все я с собой принесла домой.

[Just as that cow gave milk, so let my cow give still more milk - 15 liters at a time, and all of it I will take home]

Each action and incantation was performed and recited three times [AA 2006]. 
The purchase and sale of an animal were accompanied by a set of ritual actions and ritual dialogue. During the transfer of the animal, the buyer was supposed to ask the seller if he was selling the cattle "sprósta" or "nesprósta" [approximately "willing" or "with reservation"].(10) The seller's answer, which the question was specifically intended to provoke, determined whether the purchase or sale of the animal was legitimized and would proceed. If the answer was "sprósta," then the animal could be taken without fear. The animal was considered to be "unspoiled" and would recognize its new cattle-shed and new owner. If the seller had to think about the answer, then this was a sign that the animal was being offered "nesprósta." In this case the purchaser was advised to decline the transaction, since the seller might be "keeping" for himself certain qualities of the animal, such as its fertility, milking capacity, and good health. After the animal was brought to the new farmyard and the former owner had departed, the purchaser would strew some grain around the yard, uttering the words:

сам собой пошел, а скотину у нас не задевай [АА 2006).(11)]

[You yourself have gone, so leave our cattle alone]

There was a prohibition against giving away anything from the household for three days after a new animal first entered the cattle-shed.

People believe that milk or other dairy products that are given away from the household or sold can spoil an animal by taking away its capacity to give milk, thus affecting the animal's health and lowering milk quality. For this reason, when the dairy products are transferred to someone else, the mistress says:

Густое молоко, густую сметану, маслицо желтое густое - все оставлею дома [AА 2006].

[Rich milk, thick cream, thick yellow butter - I keep it all at home]

To prevent spoiling, it was enough to put a grain of salt in the milk while saying these words:

Как эта соль не урочится, также и коровушка не урочилась бы [ИЯЛИ:

ВФ 1523-18].

[As this salt is not spoiled, so my little cow is not spoiled]

An animal's restless behavior was viewed as an obvious symptom of the evil eye. In such cases, the person who cast the evil eye on the animal was given a ladle with water in which he could see his reflection. Then 
this water was splashed on the animal three times: twice on the head, and a third time so that water went down its sides. If the cow shook its muzzle and body, this was a sign that the evil eye had been removed [ИЯЛИ: АФ 1537-4].(12)

An entire system of protective spells focused on the animal's movement. To prevent a cow from leaving the pasture and going into the forest, villagers would walk clockwise around the animal three times reciting a charm (“churkali”):

\footnotetext{
Чур, моя ни с места. Чур, моя ни с места. Как я стою, не трепенуся ничем, дак так и моя коровушка не трепенулася ни хвостиком, ни рожкима, ни ножкима. Будьте мои слова крепки, лепки навеки. Аминь коровушке [AА 2006].

[Chur, my own, do not move. Chur, my own, do not move. As I am standing, without stirring, so my little cow does not stir, not with her tail, not with her horns, not with her legs. Be my words strong and sticky forever. Amen to the little cow]
}

Many actions were performed to help an animal "know" its shed, that is to ensure that it would return home from pasture. After the first pasture in springtime, a cow was led over the shed's threshold on which an axe had been placed sharp edge upward. Alternatively, a belt that had been removed was placed across the threshold. Once the animal passed over the threshold, the belt was put back on with the words:

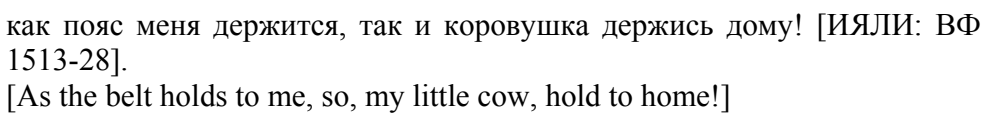

Three crosses (made of matches, woodchips, or straw taken from the farmstead or shed) might be placed beneath the threshold of the cattle shed in such a way that two crosses were covered by the third. Then the villagers would say three times, "Bless us, Lord, Christ" (Госnодu Баслови [благослови], Христос), followed by the incantation, or spell, the purpose of which was to provoke a desirable outcome [Tolstoi 1999: 259]:

Как эти крестики лежат, восплеменутся, дак так чтобы раба Божия у нас коровушка домой восплеменулася. Будьте мои слова крепки, лепки навеки. Аминь коровушке. Иди домой, ждем с нетерпеньём. Все ворота, все кресты, все дороги открыты!. After that, the cow was led from the shed [AA, 2006].

[As these little crosses lie in proximity [the idea is aggregation], so should the handmaiden of God, our little cow, return to the proximity of home. May my 
words be strong and sticky forever. Amen to the cow. Come home, we wait impatiently. All gates, all crosses, all roads are open!]

The text immediately above could also be used in a ritual that was performed if an animal was lost. At dawn, villagers took nine pegs or posts from the fence of their own garden, planed them at one end, and put them into the stove with the pointed ends outside. These were then set afire, while the following incantation was uttered over the smoke that rose ("ukhali $v$ trubku”):

\begin{abstract}
Дым ты, дым кудрявый, развались, раскатись на восемь дорожек, на девяту кудрявенькую. Как дымок выходит по заре, по всем облакам, по всем речкам, по всем озерам, так и ждем коровушку с нетерпеньём. Иди быстрехонько домой. Аминь, аминь, аминь [АА 2006];

[You smoke, curly smoke, disperse; go off along eight paths, along the ninth curly one. As the smoke goes out at dawn, to all the clouds, to all the small rivers, to all the lakes, so we wait for the little cow impatiently. Come home as fast as fast can be. Amen, amen, amen]
\end{abstract}

Дым, вейся, кружися, развевайся, скажи нам, где коровушка наша (variant: сыщи нашу коровушку [ИЯЛИ: АФ 1546-98].

[Smoke, twist, whirl, disperse, tell us where our little cow is (variant: find our little cow]

If the logs caught fire immediately, then the cow would come home at once; if not, then they anticipated the return of the animal on the ninth day.

No less substantial or representative is the body of healing incantations, dominated by "specialized" texts that the Loima villagers used to treat concrete physical or mental illnesses. Illnesses included boils, hernia, lower back pain, epilepsy, insomnia, burns, angina, toothache, bleeding, joint pain, anxiety, and so forth. As far as their content is concerned, the texts of healing incantations are based on mythological concepts of illness and healing, that is they are derived from folk understandings of the body part afflicted by the illness, its form, its visual appearance, possible influences of the illness on the organism, and so forth. Thus boils and throat inflammations needed to be "dried up," while "navel, groin, and other hernias (gryzha) are "gnawed" (zagryzhat') until they are:

ни в руках, ни в ногах, ни в устах, ни в легких, ни в печени, ни в крови горячей, ни в буйной голове

[neither in the hands, nor the legs, nor the lips, nor the lungs, nor the liver, nor in the hot blood, nor in the turbulent head]

FOLKLORICA 2009, Vol. XIV 
A burn was "put out" like a fire by pouring three buckets of water over it. Insomnia (bessonitsa) was treated by addressing a request to the dawn or dusk (zaria-zarianitsa) to "give sleep (sonnitsa)." Convulsions and epilepsy (rodimets) were "chopped off": a child suffering such ailments would be covered by a tub. Branches would then be placed on the tub (the informant mentions birch). Then the following words would be uttered four times: "I chop off all the pains-illnesses" (все боли-хвори отрубаю); meanwhile, an axe was used to imitate the action of chopping from all four sides of the tub [ИЯЛИ: АФ 1536-53].

These texts are entirely traditional in form and style. We can identify several optional constituent elements of the incantation: a section which contains the characteristics of the illness and a description of the treatment, an operational message, stating the desired outcome, a ratification, and the final "Amen." The distinctive characteristics of attested healing incantations are conciseness, brevity, and frequent syntactic parallelism, for example:

Как огонек горит, так и боляток пусть сгорит у раба Божьего [ИЯЛИ: AФ 1536-35];

[As the flame burns, so let the carbuncle [on the body] of the servant of God [Name] burn itself out]

Как эта матница в избе сохнет, так же бы сырая жаба у рабы Божьей сохла. Аминь, аминь, аминь [ИЯЛИ: АФ 1540-16]

[As the tie-beam in the hut dries out, so may the inflammation of the handmaiden of God [Name] dry out. Amen, amen, amen"]

Как сучок засох, так и у раба Божьего Ивана пусть засохнет чириек [ИЯЛИ: АФ 1536-40].

[As the knot [in the wood] dried up, so should the servant of God Ivan's boil dry up]

Hardly any so-called "universal" charms intended to cure any and all illnesses are attested, but one text of considerable complexity was recorded. This text consists of an exposition containing the description of the speaker's movements to the place where a magic helper is met; a narrative portion with a list of illnesses and those who caused them; a ratification; and the final "Amen":

Если человек болеет и считает, что кто-то его заколдовал, молитва тоже есть: «Я, раба Божья Александра, пойду, перекрестясь, пойду, благословлясь, из двери, из дверей на улицу, с улицы в чистое поле. В чистом поле щука-калыга железные зубы, оловянные глаза, ела бы поедала притчи, уроки от двенадцати болей, от двенадцати хворобей, от 
щипоты, ломоты, хворобы, от грудной боли, от ушной, головной, ручной, спинной, горла, носа, глаза, рук, рта, языка, спины, коленей, от бабы-простоволоски, от бабы-пустоголоски, от врага и злодея, от колдуна и колдуньи, от всякого негодяя. Будьте слова крепки, лепки, тверды и правильны. Во имя Отца и Сына, Святого Духа. Аминь» [ИЯЛИ: АФ 1536-37].

[If a person is ill and thinks that someone has bewitched him, there is a prayer for this: "I, the handmaiden of God Alexandra, will go, crossing myself, I will go, blessing myself, out of the door, out from the door to the road, from the road to the open field. In the open field an iron-toothed, tineyed pike fish (щука-калыга) with metal teeth nibbled at and ate up unfortunate accidents [pritchi], evil eyes [uroki](13) caused by twelve pains, twelve illnesses, bleeding, rheumatism, diseases, chest pain, ear and head pains [informant's commentary: the speaker lists everything that ails him or her], hand, back, throat, nose, eye, mouth, tongue, and knee pain, that come from the loose woman, from the rumor-monger, from the enemy and evildoer, from the sorcerer and the sorceress, from any villain. May my words be strong, sticky, firm and right. In the name of the Father and the Son, Holy Spirit. Amen"]

Treatment of some ailments was performed without verbal accompaniment. If a child had a crying fit, for example, all corners of the table were washed. Then the water was used to rinse the loops, or eyes, of the door hooks (the water was "passed" through the door hooks). Then the child was washed in this water. If the child was being treated for fright, all the corners of the table were washed and then the child was washed in that water, and the water poured out outside the house "left backhand" (naupokoi). The hair on the child's head was snipped in three places, placed on hot coals, and the child was made to inhale the smoke. Infants born with lanugo hair had their excess body hair removed in the bath-house. After a few minutes in the steam heat, the new-born's back and shoulders were smeared with a soft dough. The infant was then covered with a diaper and massaged.

Numerous informant commentaries indicate that there was wide dissemination of love incantations and charms in the Loima tradition. Long poetic texts intended to inflame passion or to cool ardor are few; the majority of recorded love charms are brief, laconic, and structured on comparison. One example is the following:

как эта елочка сохнет, так и мой дружок пусть подсохнет

[As this fir tree dries up, so may my dear one yearn [for me]].

Love charms (prisushki) include traditional formulas, such as "asking for beauty," "asking for the object of the love charm to experience yearning 
(sukhota) and suffering" and "expressing a wish for the love and favor of the object of the love charm." For example:

На воду синиста, на мое лицо белиста, на мое лицо красота, на раба Божия сухота. Не мог бы он без меня не жить, не быть, ни дни дневать, ни ночи ночевать, все бы на меня зрил, смотрил, очей не сносил. Аминь [ИЯЛИ: АФ 1547-46].

[Blue for the water, white for my face, beauty for my face, and yearning for him, the servant of God [Name]. Let him not be able to live without me, not exist, not live a day, not sleep a night; let him see me, look at me, not take his eyes from me. Amen] (14).

An incantation for beauty, spoken by girls before leaving the house uses the traditional motif of "miraculous garments." Celestial bodies such as the red sun, stars, and the moon are mentioned as space decorations.

Стою я, раба Божья, благословеся, пойду, перекрестеся, и выхожу я из дверей во двери, из ворот в ворота, на красное крылечко. На красном крылечке белым светом я умьюся, красным солнцем снаряжуся, звездочкими обвешуся, месяцем опояшуся. Не было бы меня, рабы Божей, толще, не было бы тоньше, не было бы складня, не было сгладня, чтобы всех была басяе. Все бы на меня глядели-смотрели и завидовали [ИЯЛИ: АФ 1547-43].

[Here I stand, the handmaiden of God, blessing myself, I go, crossing myself, I walk out of the door into the door, out of the gate into the gate, onto the beautiful (krasnoe) porch. On the beautiful porch I wash myself in the bright light, I dress myself in the red sun, I hang stars round my neck, I gird myself with the moon. No one would be plumper than I, the handmaiden of God, no one more slender, no one better built, no one smoother, so that I would be more fabulous than anyone. Everyone would look and gaze at me and envy me.]

We also have data on the various ways and means used to evoke yearning in the beloved. The use of sweat, menstrual blood, the practice of burning the love object's hair while uttering charms, and the practice of cutting down a small tree are all attested. Equally known is the practice of giving the spouse a drink containing canine fecal matter collected on Great Thursday to encourage the couples' separation.

Magic texts that regulate social interaction, protect people from acts of nature, and seek to affect household and agricultural life are all attested and magic texts linked to calendrical and life cycle rituals are represented by a small number of variants. On the holiday of the Intercession of the Mother of God [Pokrov; 14 October N.S./1 October 
O.S.), married women uttered incantations using an imperative formula for wealth and prosperity:

В каждый угол, первый снежок как пойдет, снежок немножко бросишь: «Батюшка Покров, покрой землю снежком, а меня, рабу Божью (имя рек), добром-животом, скотом». Скот чтобы жил ладом [ИЯЛИ: АФ 1545-20].(15)

[At the first snow, throw some snow into each corner and say: 'Little Father Pokrov, cover the land with snow and cover me, the handmaiden of God [Name], with goods and cattle' Let the cattle live in harmony]

So that the roof might not be blown off the house, on Holy Thursday the villagers threw onto the roof a $\log$ or a small stone on which was written "I put weight on you for the whole year" [ИЯЛИ: АФ 1545-12]. If a person died in the house, a small stone was placed in the holy corner (krasnyi ugol), under the icons. On the fortieth day the relatives recited the following:

\footnotetext{
Как камешек лежит, не воротится, не поворачивается, так и душа раба божьего не вернулась домой

[As the stone lies, not returning, not turning around, so the soul of the servant of God should not return home]
}

Then the stone was thrown out over the left shoulder [ИЯЛИ: АФ 152163]. After the coffin with the deceased was carried out of the house, grain was strewn on the porch with the words:

Пойди сам собой, а у нас из дома никого не уводи [АА, 2006].(16)

[Go your own way by yourself and take no one from our house with you]

Brief incantations uttered at weddings included good wishes for a wealthy and easy life together and incantations directed to the union (or separation) of the young couple. They were built on comparisons. For example, the young couple would be sprinkled with hops (17) while the words "let life be as easy/as light as hops" (Пусть жизнь будет легкая как хмель) were uttered. The good wishes verbally express the actual qualities of hops, namely the fluffiness. To separate a couple, one would toss fur from a cat and dog at the couple's house, saying:

Как кошка да собака живут худо, грызутся, так же и (имя рек) пусть живут [ИЯЛИ: АФ 1545-9, etc.]

[As a cat and a dog live badly together and fight, so may [Names] live the same way]. 
It is interesting to note that cats and dogs appear in a description of wedding practices collected in the Viatskii region in the 1850s. Before the wedding procession set out for the church, the best man was supposed to demand that "there be no dogs or cats." The belief was that if the wedding procession encountered a dog or a cat or if a dog or a cat ran between the bride and groom, then the new couple would quickly separate [РГО. Р. 10. Оп. 1. Ед.хр. 28. Л. 14 об.].

Texts associated with agricultural labor contain the following spell said when harvesting grain crops. It is spoken over the last sheaf and has a productive meaning:

Последний дожинают сноп, вот Илье Бороду и завертывают, колоски тут завернут, тут и оставят их, не срежут, что это Илье борода: «Илье борода, коню - голова, хозяину - в сусек спарина», чтобы хлеб все время [был] [ИЯЛИ: ВФ 1529-17];

[When they harvest and get to the last sheaf, they roll up the ears of grain on the stalks for this is the Beard (Boroda) of Il'ia, and they will leave this sheaf, they will not cut it, for this is Il'ia's beard: "Il'ia gets the beard, the horse gets the head, the master gets goods in the granary," so that there will always be bread]

Последнюю полоску будешь жать, такое кустик оставляёшь маленький, и сверху маленько замотаешь [и приговариваешь]: «Коровушка съест, дак теленочка ро́дит, лошадка съест, дак жеребеночка ро́дит, овечка съест, дак овечку ро́дит». Потом там скот ходит, кто знает, может, кто и съест [ИЯЛИ: АФ 1549-24].

[When you harvest the last strip, then leave a small clump, tie it up a bit at the top [and say]: "If a cow eats this, it will bear a calf; if a mare eats this, it will bear a foal; if a ewe eats this, it will bear a lamb." Then when the cattle roam there, perhaps one of them will eat it]

Charms to prevent fire and theft often have motifs such as a stone mountain or iron paling which provides a barrier and end with Amen:

Чур, моя крепость, чур, мой дом. Вкруг моего двора камена гора, аминем обнесена [ИЯЛИ: ВФ 1532-5, 6].

[Chur, my fortress, chur, my house. Surrounding my yard is a stone mountain, enclosed by an Amen]

Incantations recited before leaving a journey mention holy helpers who will lead the way:

Ангел по дороженьке, Христос на пути, Николай Угодничек, дороженьку свети, помоги мне, рабе Божьей (имя рек), выбраться на путь истинный [ИЯЛИ: АФ 1540-29]; 
[An angel along the road, Christ on the way, St. Nicholas light my path, help me, the servant of God [Name], find the true way]

Крест-креститель, крест-спаситель, от всех бед оградитель, укажи дороженьку [ИЯЛИ: АФ 1538-15];

[Cross-baptizer, cross-savior, keeper from all harm, show me the way]

Спустился Господь с небес, спустил животворящий крест от змей, от зверей и от злых людей, от лютого врага, чтобы спасти меня, рабу Божью Валентину. Аминь, аминь, аминь [ИЯЛИ: АФ 1540-24].

[The Lord came down from heaven, He sent down a life-giving cross to protect me, the handmaiden of God Valentina, from snakes, from beasts, from evil people, from the vicious enemy. Amen, amen, amen]

In the repertoires of various informants there are stylized texts, such as this charm recited in the bath-house:

Березонька пушистая, березонька душистая, дай мне твоей силушки, твоей моготушки, какую ты берешь из земли-матушки, чтоб я не гнулася, не качалася ни в чистом полюшке, ни в дубравушке, ни от ветра могучего, ни от снега сыпучего, ни от дождика частого [ИЯЛИ: АФ 1536-41].

[Fluffy birch, fragrant birch, give me some of your strength, the power that you take from mother earth, so that I might not bend, might not sway, in either the open field or the forest grove, from either a mighty wind or falling snow or frequent rain]

Incantations and non-canonical prayers intended for daily use, that is those recited before retiring and upon awakening, against spoiling, when washing, before a journey, and so forth, are a vivid part of Loima tradition. The majority of these texts express the idea of "enclosing the space around the speaker with the aid of holy helpers or a cross":

Иду, перекрестясь, иду, благословясь. Рядом со мной ангелы-хранители, надо мной Господь Бог, передо мной Пресвятая Богородица [ИЯЛИ: АФ 1537-25; uttered before setting out on a journey];

[I go, crossing myself, I go, blessing myself. Beside me are guardian angels, above me is the Lord God, before me is the Most Holy Mother of God]

Спать ложусь, крестом крещусь, крестом Христа призываю, крестом врага отгоняю. Враг-сатана, прочь от меня, нет тебе дела до меня, до рабы Божьей Валентинушки [ИЯЛИ: АФ 1540-23; uttered before going to sleep];

[I go to bed, I cross myself with the cross, I call on Christ with the cross, with the cross I drive the enemy away. Enemy-Satan, get away from me, you have no business with me, with the handmaiden of God Valentinushka] 
Богородица в головах, ангелы в дверях, апостолы по углам, [нрзб] по бокам, святая вода в храме. Я, раба Божья (имя рек), святой водой окроплюсь, святым духом запрусь, животворящим крестом перекрещусь. Аминь, аминь, аминь [ИЯЛИ: АФ 1540-30];

[The Mother of God at the head, angels at the doors, apostles in the corners, [unclear] on the sides, holy water in the church. I, the handmaiden of God [Name], will sprinkle myself with holy water, will lock myself in with the Holy Spirit, will cross myself with the life-giving cross. Amen, amen, amen]

Солнышко восходит, сам Иисус Христос выходит, с крестом, с евангелём, с Божьей головой. Благослови меня, Господи, на раннёе вставаньё, на тихоё дыханьё, благослови меня, Господи, по матушкеземле пройти, талант найти. Пресвятая Богородица, меня веди, Иисус Христос, иди впереди меня, рабу Божью (имя рек) стереги [ИЯЛИ: АФ 1547-23, recited for every day].

[The sun rises, Jesus Christ himself appears with the cross, the Gospel, the God's head (meaning God's blessing). Bless me, O Lord, so that I may rise early, breathe quietly; bless me, O Lord, so that I may walk on mother-earth, and find happiness. Most Holy Mother of God, guide me; Jesus Christ, go before me, preserve the handmaiden of God [Name]]

The symbolic enclosure of space may also be achieved by multiple repetitions of a key word:

Крестом крещуся, крестом хранюся, крестом врага отгоняю, крестом Христа призываю [ИЯЛИ: АФ 1536-52], etc.

[With the cross I cross myself, with the cross I preserve myself, with the cross I drive the enemy away, with the cross I call on Christ]

Incantations against the evil eye and spoiling occupy a lesser place in recorded folklore. In their content, stylistics, and choice of structural elements, they are entirely traditional Northern Russian texts. In one of the incantations, the central image is that of a river that washes away all aches, all forms of grief, all accidents, spoiling:

Быстрая ричка, чистая водичка, рвешь ты пенья-коренья, желты песка, круты бережка. Сорви и стащи с меня, с рабы Божьей Зинаиды, все боли, скорби, притчи, уроки, унеси во синеё море. Во синём море зеленым мошком подернёт, желтым песком засыплёт, будет годы годовать, веки вековать, замок в море, ключ в небе. Во веки веков, аминь [ИЯЛИ: АФ 1547-44].

[Fast river, pure water, you tear up stumps and roots, your sand is yellow, and your banks are steep. Tear off and pull off from me, from the handmaiden of God Zinaida, all aches, all grief, accidents, spoiling, and carry them out to the dark blue sea. In the dark blue sea they will be coated with green moss and covered with yellow sand, they will stay there for years and years, for 
centuries and centuries, the lock is in the sea, the key in the sky. Forever on to ages. Amen.]

Another text describes the progressive movement of the person toward a sacred center and expresses the wish that the properties of cosmic bodies (inaccessibility, purity) be transferred to the speaker:

Стою я, раба Божья, благословеся, пойду, перекрестеся, из дверей во двери, из ворот в ворота, выхожу я, раба Божия, на белой свет, на утреннюю зо́рю, на красное солнышко. Как белой свет, утреннюю зо́рю, красное солнышко никто не может ни запретить, ни испортить, ни мужик-еретик, ни баба-колдовка, ни девка-простоволоска. Еретные слова, пойте в поле, в поле стоит столб, из столба в камень, еретнику в ретивое сердцо. Аминь [ИЯЛИ: ВФ 1530-29]

[I stand, the handmaiden of God, blessing myself, I shall go, crossing myself, from doors to doors, from gates to gates. I, the handmaiden of God, emerge into the wide world, into the morning dawn, out to the red sun. No one can interdict or spoil the wide world, the morning dawn, or the red sun, not the heretic, not the sorceress, not the loose woman. Heretical words, go into the field, in the field there stands a column, go from the column into a stone, then into the heretic's zealous heart. Amen].

Still another text is the result of the contamination of a canonical prayer, namely the Lord's Prayer, by an incantation against spoiling:(18)

Отче наш, да иже еси на небеса, да святится имя твое, да будет царствие твое, да будет воля твоя, да яко же земли хлеб наш насущный дашь нам днесь. И мы долги оставляем нашим должникам. Да отче наш, да не введи нас в искушение, избавь нас от всякого от лукавого, от зла. Пойду я в чисто-то поле, пробежусь по чистому-то полю, на чистом-то поле серый камень лёжит, на сером-то камне три девицы, три красавицы сидят, все обнимаются, словные наговорные [нрзб.] все слова. Будьте мои слова крепки, лепки навеки. Аминь. Этим девицам, красавицам молюсь, унижаюсь, удивляюсь, чтобы все с меня чтобы зло ушло [АА, 2006].

[Our Father Who art in heaven, hallowed be Thy name. Thy kingdom come, Thy will be done on earth. Give us this day our daily bread. And we forgive our debtors. And, Our Father, lead us not into temptation, but deliver us from the evil one, from all evil. I will go to the open field, I will run across the open field, in the open field lies a gray stone, on the gray stone sit three maidens, three beauties, embracing each other, incantational [unclear] all words. May my words be strong, sticky forever. Amen. To these maidens, these beauties, I pray, before them I abase myself, by them I am amazed, so that all evil should depart from me]

The merging of two different genres in this incantation can be partially explained by the semantics of the key words: thus "the evil one" 
(lukavyi) has a range of meanings in popular parlance, among which are "clever and scheming, perfidious, secretive and wicked (zloi), and also dangerous, insincere, feigning, double-faced, ill-intentioned. The word can also be used as a noun meaning demon, devil, Satan, the unclean one, the evil (zloi) spirit" [Dal', 1995, v. 2, 272] essentially the embodiment of evil. Clearly such a perception of the evil one provoked the appearance of the lexeme "evil (zlo)" in conjunction with the phrase "deliver us from the evil one (lukavyi)" found in the first part the text. It also motivated the distinctive post-script with the wish that "evil (zlo) should depart from me" after the Amen. This repetition is intended to increase the effectiveness of the magical text.

Analysis of available audio recordings makes it possible to speculate about the manner in which incantations were uttered. Incidentally these speculations confirm what collectors in the last century also discovered, namely that incantations are spoken in a single breath, a feat facilitated by the particular rhythmic and syntactic structure of the texts. In one interview, an informant performed in real time the incantation accompanying the ritual of searching for a lost animal. $\mathrm{He}$ used rising intonation drawing out the last word in each clause, a style referred to as a "calling hoot":

\footnotetext{
. . . Иди домо-о-о-ой. Ждем с нетерпень-ё-ём. Все ворота, все кресты, все дороги открыты-ы-ы-ы

[. . . Come ho-o-o-ome. We wait impatiently-e-e-e. All gates, all crosses, all roads are ope-e-e-n]
}

A numerical code of triplicates works at different levels of the text. It can appear in the text as a whole, only in the ratification, or in the final prayerful word "Amen." Separate lexemes are uttered three (and more rarely, nine) times, and the ritual actions that accompany the magic text are enacted the same number of times. Examples of the use of the number four are rare and occur most often in rituals or texts that symbolically enclose the space around the speaker. Such uses of the number four can be found in the treatment of epilepsy or convulsions, and in incantations for daily use and those recited before beginning a journey).(19)

Object and action in healing, animal husbandry, and other rituals remain important. Materials collected from contemporary informants show that they preserve strict regulations governing the choice of the place where and the time when rituals should be enacted. The combination of action and verbal components of rituals is also highly 
regulated. In addition, different correlations exist between action and text. People typically "talk through" the ritual beforehand, or they use synchronicity of utterance and action, or they alternate action and utterance [about correlation between verbal component and action in incantation, see: Tolstoi 1999: 241].

The structural peculiarities of written incantations show that contemporary informants prefer brief incantational phrases or texts structured by the device of syntactic parallelism that use comparative formulas [Tolstoi 1999: 243]; there are many such formulas in the repertoires of the Loima population. One example is the following: when explaining how to protect the bride from spoiling, the informant includes in his narrative brief incantational texts, the simplicity of which speak for the presupposition that they were composed spontaneously:(20) "Sticking a needle into the hem [of the bride's dress - Iu. K.], they wrapped thread around the needle and said:

Когда эта ниточка сквозь иголочку пройдет, тогда невесту (имя рек) сглазят)[ИЯЛИ: АФ 1542-55].

[When this thread passes through the needle, then the bride [Name] will be spoiled]

In another:

Невесте втыкали иголку с ниткой в подол [при этом нитку обертывали вокруг иголки]: “Только тогда разлучат рабов Божьих Ивана и Марию, когда эта ниточка пройдет сквозь ушко” [ИЯЛИ: АФ 1537-20], etc.

[They stuck a needle with thread into her hem [and wrapped the thread around the needle]: 'The servants of God Ivan and Maria will be separated only when this thread passes through the eye of this needle']

While short texts abound, complex texts with a full set of structural elements are rare. Such texts include a prayerful initiation, an introduction describing the initial actions of the speaker, a narrative and an operational message in which the mythological situation is recreated and the means of its resolution is proposed, a ratification, and an Amen. In subsequent utterings, such complex texts are recreated word for word, without any textual modifications.

Magic helpers in incantations include saints, both anonymous and named personages, anthropomorphized beings, and other entities. Magic helpers each have their own "specialization": the Mother of God, Paraskeva, and Klavdiia help with the unlocking of milk; people turn to St. Nicholas the Miracle Worker for help when they have lost their way 
while traveling; a "woman ( $b a b a)$ with three buckets of water" heals burns; "three maidens, three beauties" guard against evil; the one "universal" magic helper is Christ. Harmful individuals, capable of spoiling or bringing illness, are listed and catalogued in the texts. In the same category as sorcerers and sorceresses ("man-heretic" [muzhikeretik],"woman-sorceress" [baba-koldovka], and "evil-doer" [likhodei]) are "loose women" (baba-prostovoloska; i.e. a woman with loosened hair and uncovered head; $c f$. loose and uncovered hair as an attribute of demonic females [Tolstoi 1995: 423]), "female rumor-mongers" ( $b a b a$ pustogoloska; a foolish, shallow woman who spreads rumors and false gossip), "scoundrels" (негодяй; "a good-for-nothing, bad, stupid, immoral person" [Dal' 1995, v. 2: 509]), "evil doers" (лиходей; “evil, vindictive, crafty" [Dal' 1995, v. 2: 257]), etc. Here contemporary records preserve traditional conceptions of the ability of rancorous, talkative, immoral people to spoil and harm through their secretions such saliva and odor [Konakov 1999: 362]. Such a person can also harm through abuse which, in the popular imagination, is considered a manifestation of unclean forces and serves as a distinctive attribute of representatives of an "other" world [Tolstoi 1995: 250-253].

The color palette of Loima incantations is limited. Only a few references to color have been recorded. These include: "gold keys," "white dish" (in reference to the "unlocking of milk"), "yellow sand," "dark blue sea" (in the incantation against spoiling), "gray stone" (a variant of the sacred Alatyr'-stone). Other imagery traditionally found in incantations and charms that appears regularly includes the following: "iron fencing" (zheleznyi tyn), the adjective "miraculous", a wish for beauty, a wish for the object of the charm to experience yearning (sukhota), a wish for love and the love object's favor, and various formulaic lists such as the enumeration of illnesses, parts of the body, and causes of harm.

Popular terminology applied to magical texts in general and healing charms in particular shows that the inhabitants of Loima see them as prayers, passages (stateiki), and words. The subjects of incantational rituals are, as a rule, elderly women. This is reflected in such appellations as "old woman," "grandmother." We also encounter references such as "wise woman" (znaiushchaia, znakharka), which imply that these women are seen as having magical knowledge. The term "word-blower" (slovoduika, fem.) which is widely attested in this tradition, reflects how the healer acted upon her patient. 
Specifically, the woman would recite the incantation, "blowing the words" onto water, salt, or food stuffs such as sweets, eggs, sugar, which were then given to the patient.

Contemporary fieldwork among the Russian enclaves of the Loima region reveals an active folklore tradition which uses charms and incantations for a wide variety of purposes.

\section{NOTES}

1 For a brief overview of Loima folk culture, see Vlasov and Kaneva 2006: 25-26. The Loima tradition has been addressed in works devoted to individual folkloric and ethnographic phenomena of family and life ritual, in particular wedding incantations and rituals [Krasheninnikova 2005, 2007] and funerary and commemorative rituals [Krasheninnikova 2009].

2 Primary materials introduced in this article were recorded in the village of Loima and in adjacent villages in 2004 and 2006. Portions of this audio and video archive are held in the folklore collection of the Institute of Language, Literature, and History of Komi, a part of the Ural Section of the Russian Academy of Sciences. Other portions are in the author's private archive. The material on incantations is based on interviews with 28 informants, mostly women, born between 1909-1938.

3 The above applies not only to the Loima villages. A decrease in the use of incantations for animal protection can also be explained by the expansion of veterinary medicine and by a sharp reduction in the number of cattle kept by collective (in part by the complete absence of socialized farming) and private enterprises.

4 Compare with the records of Northern Russian incantations containing two parts. See also the invocation of the domovoi and incantation wishes from, for example, Pinezhskii, Vinogradovskii raiony Arkhangelskaia oblast' [Adon'eva and Ovchinnikova 1993, 33-34, 37, № 102-108, 119], etc.

5 In Northern Russian tradition, texts with the motifs "a sorcerer spoils a cow," or "a sorcerer locks milk" have become widespread. These texts list the attributes of the "spoiled" animal: the cow ceases to give milk, becomes restless, aggressive, does not let the mistress touch her, its udder becomes inflamed.

6 St. George's Day, Egor'ev den'. 6 May N.S./23 April O.S. is the feast day of St. George the Victory-Bearer (Georgii Pobedonosets), who is also the patron of livestock. Traditionally, first pasture takes place on 
this day. In reality, the pasturing of animals could only begin after sufficient grass had grown in the pasturage, but the mention of Egor'ev den' as the "starting point" of summer pasturage is consistent across interviews with various informants.

7 Pussy Willow Sunday, Verbnoe Voskresenie is Palm Sunday in the Western Church. It is the sixth Sunday of Lent and the last Sunday before Easter. It celebrates Christ's entry into Jerusalem [Matt.: 1-9]. In the Russian North, this day was celebrated by bringing branches of pussy-willow to the church to be blessed. The pussy-willow was then taken home and placed before the icons until the following year. It could be used for special rituals, including first pasture.

8 Velikii Chetverg, Strashnyi/Strastnoi Chetverg, Great Thursday, Holy Thursday, Maundy Thursday (Anglican). In the imagination of the inhabitants of the Russian North, the Thursday of Holy Week, the day before Good Friday, is rich in beliefs, interdictions, and signs. It is saturated with ritual practices directed at insuring the well-being, prosperity, and health of the village for the coming year. Our expeditionary records concerning this day, made in Loima, confirm and supplement known data previously collected in the Russian North.

In order to promote their own marriage, girls "swept" the road for their bridegrooms on Holy Thursday. They took a wooden harrow, chopped it up, and scattered the pieces at the crossroads [ИЯЛИ: АФ 1538-9, 1539-29]. On the roof, they shifted the ridgepole (okhlupen') [ИЯЛИ: ВФ 1506-41]. Before sunrise, the mistress of the house performed several rituals directed at the well-being of the family, the fertility of cattle, and the strengthening of health. Typically, she counted money ("so that money would be present the year round"), she stirred the sour cream, and made butter [ИЯЛИ: АФ 1541-19]. A log, wood chip, or small stone with the charm "I put weight on you for the whole year" would be tossed up onto the roof, so that the wind would not blow the roof off [ИЯЛИ: АФ 1545-12]. Villagers washed with river water so that "eyes would see well" [ИЯЛИ: АФ 1544-11]. A tradition of "washing up with silver," characteristic of the Viatka area, has also been recorded [Vlasov and Kaneva 2006: 25]. In the Loima region: a silver or gold coin would be placed in the wash basin and then everyone washed with this water [ИЯЛИ: ВФ 1524-26].

Ritual dialogues, spoken by the masters of the house on Holy Thursday, have been recorded. The purpose of these dialogues was to encourage cattle to come home from pasture and to recognize their own cattle-shed. The mistress of the house, standing in the road before an 
open window, would ask: "Is the cow at home?" The master stood near the window and answered, "At home." This dialogue was repeated until all of the animals of the farmstead were mentioned.

Informants explain existing interdictions against giving anything away on this day as mitigating the danger of losing one's property, suffering damage, or losing happiness. For example, in one of the oral narratives, the informant stated that his giving away a small amount of hay was the reason for the subsequent loss of all the hay and cattle in the household [ИЯЛИ: ВФ 1521-55]. Men simulated fishing on this day: they climbed on the roof and placed logs in their fishing nets, so that "much fish would be caught (variant: large pikes would be caught)" [ИЯЛИ: АФ 1541-19].

Because Great Thursday is also called "Terrible Thursday" (Strashnyi, Strastnoi Chetverg), it became linked in the popular imagination with the activity of sorcerers, and thus with the special vulnerability of cattle and people at this time. With the aim of protecting themselves from spoiling and the evil eye, people drew crosses on the doors of the cattle-shed and the house. They typically walked round all the residential and farmyard buildings on this day, reciting prayers or strewing salt blessed on Holy Thursday, or sprinkling water taken from three streams [ИЯЛИ: АФ 1554-16]. Items collected by a sorcerer on Holy Thursday were considered especially dangerous and animals could be spoiled if hair or wool was cut from their coat, or if their excrement was collected on this day. Similarly, spouses could be separated if given a drink containing canine fecal matter collected on Holy Thursday [ИЯЛИ: АФ 1545-8].

9 Folk tradition includes the notion that the evil eye may be given unintentionally or accidentally and those who are capable of casting the evil eye inadvertently are said to have a "bad eye." It is also said that their blood does not meet, or "agree with," the blood of the person spoiled, [ИЯЛИ: АФ 1537-3, 4]. To avert the evil eye, one must stick a pin in one's hem so that it was visible. Other powerful preventative measures included placing chicken droppings in footwear, under the foot [ИЯЛИ: АФ 1537-23, 1542-55], using "Thursday" salt, and so forth. Spoiling (porcha) by a sorcerer is considered always intentional, never accidental.

10 This ritual has been recorded not only in reference to the buying or selling rituals of cattle; any transfer (of cattle, seed, products) is accompanied by ritual dialogue.

11 See a similar use of grain in a funeral ceremony, below. 
12 A similar treatment was applied to affected children. The child was positioned under the tie-beam of the house and splashed with water into which the person who had cast the evil eye had earlier been made to look.

13 The use of the words pritcha and urok is noteworthy. Pritcha usually means "parable" and urok means "lesson." The two words can also be used synonymously. Here pritcha (var. pritka) means 'unfortunate accident, sudden illness, hysterics, fainting fits, etc.' and urok means 'spoiling, evil eye.' Urok and its verb, urochit' carry the meaning of casting the evil eye or spoiling someone by means of sorcery, or by sending an illness [Dal' 1995, v. 3: 452; v. 4: 508-509]. The image of a pike with iron teeth biting a hernia or other illness appears consistently [Poznanskii 1995: 173 and next]. Thus, the iron-toothed pike (the wonderful helper) consumes spells, curses, spoiling, and disease. A variant of the iron-toothed pike image is a bird that scratches the illness out of the patient [ИЯЛИ: АФ 1702-20, 25; Vilegodskii raion Arkhangelskaia oblast'].

14 The charm is based on the word play where sukhota means not only "dryness," but also "melancholy," "love languor, depression, spleen." In dictionary definitions sukhoi (dry) can also refer to being deprived of life juices, being dysfunctional, sickly, ailing [Ozhegov 1987: 678]. The opposite is fatness, obesity [Dal' 1995, v. 4: 365] and these are considered as signs of health and plenty in traditional folk belief. The verb sushit' ('to dry') is found in the meanings of: 'to make someone dry,' that is 'bad, thin, emaciated' [Ushakov 2004: 1080], 'to bring to exhaustion, torment, worry' [Efremova 2000]. Sukhaia lubov' means platonic love [Ushakov 2004: 1079]. The root (sukh) refers to dryness, hence the association of dryness and pining, on the one hand, and the name of the sub-genres (prisushka, otsushka) on the other. In sympathetic magic, similarity is sufficient to constitute identity [about "dry" and "dryness" in traditional belief, love magic, and charms, see Tolstaia 2008: 53-68; Toporkov 2005: 158-159].

15 Cf.the productive incantation, widely-disseminated in the Russian North, said by maidens on the Pokrov holiday: "Pokrov Little Father, cover the ground with snow and me with a bridegroom" (Покров батюшка, покрой землю снежком, а меня женишком) [ИЯЛИ: АФ 1701-14, etc.]. Here pokrov (intercession, veil, and covering) and pokryt' (the verb "to cover") are identified. It should be noted that "pokryvat" also means to endow, to bestow. 
$16 C f$. the incantation "Here is some rye for you, but don't touch our family!" (На тебе рожь, а нашу семейку не трожь!). This incantation helps explicate the custom of strewing grain at burial [Anikin 1998, № 2439; cited in Tolstoi 1999: 241].

17 Hops (khmel') - plant, Humulus lupulus L.

18 In this case, we may speak about contamination, but we must also take into consideration the informant's own comments, which demonstrate that she perceives the text as a single entity, calling it a prayer. In many rituals, prayers were read before the recitation of other sacral texts (incantations, charms) [Tolstoi 2004: 278].

19 The use of the number three is connected with its interpretation as an "image of absolute perfection" and is explained by the fact that this number represents "an ideal structure with a separate beginning, middle and end. < . . > an ideal model of any dynamic process" [Toporov 2005: 234-235]. The number four symbolizes "static integrity, an ideally stable structure" [Toporov 2005: 235].

20 The "particular simplicity" of incantations from the seventeenth century allowed E.N. Eleonskaia to conclude that "many of them were composed as the need arose" [Eleonskaia 1912: 613].

\section{BIBLIOGRAPHY}

Adon'eva, S. B and O. A Ovchinnikova. 1993. Адоньева, С. Б., и О. А. Овчинникова, ред-ы. Традиционная русская магия в записях кониа XX века [Traditional Russian Magic in the Records of the Late $20^{\text {th }}$ Century]. Санкт-Петербург.: Frendlikh-Taf.

Anikin, V. P., (ed.). 1998. Аникин, В. П., ред. Русские заговоры и заклинания. Материаль фольклорных экспедииий 1953-1993 [Russian Incantations and Charms. Materials from folklore expeditions of 1953-1993]. Москва: Изд-во Московского университета.

Dal', Vladimir. 1995 [2 $2^{\text {nd }}$ ed. 1880-1882]. Даль, В. И. Толковый словарь живого великорусского языка, в 4-х томах [Explanatory Dictionary of the Living Great Russian Language]. Москва: Терра.

Efremova, T. F. 2000. Новый толково-словообразовательный словарь русского языка. Автор Т. Ф. Ефремова. [New Dictionary of Definitions and Wordformation of Russian Language]. 2000 (http://www.speakrus.ru/index.htm) 
Eleonskaia, Elena. 1912. Елеонская, Е. Н. “Заговоры и колдовство на Руси в XVII и XVIII столетиях" [Incantations and Sorcery in Rus' in the $17^{\text {th }}$ and $18^{\text {th }}$ Centuries]. Русский архив 4: 611-624.

Eleonskaia, Elena. 1917. Елеонская, Е. Н. К изучению заговора и колдовства в России [On the Study of Incantations and Sorcery in Russia]. [Шамордино]: Издание Комиссии по народной словесности при Этногр. отд. И[мп]. О[-ва] Л[юбителей] $\mathrm{E}$ [стествознания] А[нтропологии] и Э[тнографии].

Konakov, N. D (ed.). 1999. Конаков, Н. Д., гл. Ред. Мифология Коми. Энииклопедия уральских мифологий [The Mythology of Komi. Encyclopedia of Ural Mythologies]. Т. 1. Москва: ДИК.

Krasheninnikova, Iu. А. 2005. Крашенинникова, Ю. А. “Свадебный обряд Лоймы в памяти современных носителей традиции: свадебные чины и их приговоры (по материалам фольклорной экспедиции 2004 г.) [Loima Marriage Rituals in the Memory of Contemporary Bearers of the Tradition: Marriage Roles and Their Incantations (based on materials collected by the folklore expedition of 2004]." История, современное состояние, перспективы развития языков и культур финно-угорских народов. Сыктывкар: Институт языка, литературы и истории Коми научного центра УрО РАН. 259-263.

Krasheninnikova, Iu. А. 2007. Крашенинникова, Ю. А. “Свадебные приговоры и диалоги Прилузского района Республики Коми” [Marriage Incantations and Dialogues of the Priluzsk Region of Komi Republic]. Славянская традиционная культура $и$ современный мир. Материалы междунар. науч. конференции. Вып. 10. Москва: Министерство культуры Российской Федерации, Государственный республиканский центр русского фольклора. 33-51.

Krasheninnikova, Iu. А. 2009. Крашенинникова, Ю. А. "Похороны 'по-репному' (о некоторых фактах похоронно-поминальной обрядности северных русских)" [Funerals in the "Repin" Manner (on certain facts about the funerary-commemorative rituals of the Northern Russians]. Антропологический форум. Вып. 10. СанктПетербург. 299-310.

Kukharenko, Svitlana. 2007. "Animal Magic: Contemporary Beliefs and Practices in Ukrainian Villages" Folklorica XII: 53-76.

Ozhegov, S. I. 1987. Ожегов, С. И. “Словарь русского языка” Под ред. Н. Ю. Шведовой. Изд-е 18. [Dictionary of the Russian 
Language, ed. N. Iu. Shvedova, edition 18]. Москва: Русский язык.

Poznanskii, N. F. 1995. Познанский, Н. Ф. Заговоры. Onыm исследования происхождения и развития заговорных формул. [Incantations. Exploration of Genesis and Development of incantational forms]. Москва: Индрик

Tolstaia, S. M. 2008. Толстая, С. М. "Семантический параллелизм *kras- и *květ-“. [Sematic Parallels of "kras-" and "kvet-"]. В книге: Толстая, С. М. Пространство слова. Лексическая семантика в общеславянской перспективе. [Space of the Word. Lexical Semantics in Pan-Slavic Perspective]. Москва: Индрик. 121-134.

Tolstoi, N. I., (ed.). 1995-2004. Толстой, Н. И., ред. Славянские древности. Этнолингвистический словарь в пяти томах [Slavic Antiquities. An ethnolinguistic dictionary in five volumes]. T.1-3. Москва: ИМО.

Toporkov, A. L. 2005. Топорков, А. Л. Заговоры в русской рукописной традиции XV-XIX вв.: История, символика, поэтика. [Charms in Russian Manuscript Tradition of the Fifteenth-Nineteenth Centuries: History, symbolism, Poetics]. Москва: Индрик.

Toporov, V. N. 2005. Топоров, В. Н. “О числовых моделях в архаических текстах" [On Numerical Models in Archaic Texts]. B книге: Топоров, В. Н. Исследования по этимологии и семантике. Т. 1: Теория и некоторые частные ее приложения. Москва: Языки славянской культуры. 226-273.

Ushakov, M., (ed.). 2004. Ушакова. М. Под ред. Большой толковый словарь русского языка [Large Conversational Dictionary of the Russian Language]. Д. Н.: ООО «Издательство АСТ»: ООО «Издательство Астрель».

Vlasov, A. N. and T. S. Kaneva. 2006. Власов, А. Н. и Т. С. Канева. "К проблеме феноменологии локальных традиций (по результатам исследования фольклорной культуры Европейского СевероВостока России)" [On the Problem of the Phenomenology of Local Traditions (on the basis of the study of the folklore culture of European North-East Russia]. Народная культура Европейского Севера России: региональные аспекты изучения. Сыктывкар: Сыктывкарский государственный университет. 16-39.

Zherebtsov, I. L. 1994. Жеребцов, И. Л. Где ты живешь. Населенные пункты Республики Коми: Историко-демографический 
справочник [Where You Live. Populated Areas of Komi Republic: an historical-demographic handbook]. Сыктывкар: Коми книжное изд-во.

\section{ABBREVIATIONS}

AА - Архив автора, записи 2006 г. (Author's personal archive, records of 2006)

ИЯЛИ - Фольклорный фонд Института языка, литературы и истории Коми научного центра Уральского Отделения РАН, Сыктывкар (Folklore collection of the Institute of Language, Literature, and History of the Komi Research Center, Ural Section of the Russian Academy of Sciences, Syktyvkar)

АФ - аудиофонд (audio collection)

ВФ - видеофонд (video collection)

РГО - архив русского географического общества, СанктПетербург (the archive of the Russian Geographical Society, SPb). 